Boston University School of Law

Scholarly Commons at Boston University School of Law

Faculty Scholarship

$11-2018$

\title{
The Rhetoric of Bigotry and Conscience in Battles Over "Religious Liberty v. LGBT Rights"
}

Linda C. McClain

Boston University School of Law

Follow this and additional works at: https://scholarship.law.bu.edu/faculty_scholarship

Part of the Civil Rights and Discrimination Commons, and the Family Law Commons

\section{Recommended Citation}

Linda C. McClain, The Rhetoric of Bigotry and Conscience in Battles Over "Religious Liberty v. LGBT Rights", in Religious Freedom, LGBT Rights, and the Prospects for Common Ground 212 (William N. Eskridge Jr and Robin Fretwell Wilson ed., 2018).

Available at: https://scholarship.law.bu.edu/faculty_scholarship/275

This Book Chapter is brought to you for free and open access by Scholarly Commons at Boston University School of Law. It has been accepted for inclusion in Faculty Scholarship by an authorized administrator of Scholarly Commons at Boston University School of Law. For more information, please contact lawlessa@bu.edu. 


\title{
BU School of Law
}

\section{THE RHETORIC OF BIGOTRY AND CONSCIENCE IN BATTLES OVER “RELIGIOUS LIBERTY V. LGBT RIGHTS”}

\author{
Boston University School of Law \\ Public Law \& Legal Series Paper No. 18-05
}

Religious Freedom, LGBT Rights, and the Prospects for Common Ground (William S. Eskridge, Jr. \& Robin Fretwell Wilson, eds., Cambridge University Press, forthcoming)

\section{Linda C. McClain}

Professor of Law and Paul M. Siskind Research Scholar

Boston University School of Law 


\title{
The Rhetoric of Bigotry and Conscience in Battles over "Religious Liberty v. LGBT Rights"
}

\author{
Linda C. McClain* \\ Professor of Law and Paul M. Siskind Research Scholar, Boston University School of Law
}

\begin{abstract}
Charges, denials, and countercharges of "bigotry" have a long history in debates over the evident conflict between LGBT rights and religious liberty. ${ }^{1}$ In recent controversies, a frequent claim is that religious individuals who oppose changes in the legal definition of civil marriage and seek conscience-based exemptions from state nondiscrimination laws that include "sexual orientation" as a protected category are being "branded" as bigots. Two prominent examples are the dissenting opinions in Obergefell v. Hodges, ${ }^{2}$ in which the United States Supreme Court held that same-sex couples "may exercise the fundamental right to marry in all States," and the arguments made in defense of merchants who object to providing wedding-related goods and services to same-sex couples, such as in Masterpiece Cakeshop, Ltd. v. Colorado Civil Rights Commission, which the Supreme Court will decide during its 2017-2018 term. Critics of the application of nondiscrimination laws to such merchants even flip the (explicit or implicit) charge of bigotry to apply to the opponents of religious exemptions.
\end{abstract}

What does it mean to assert that a judicial opinion or a civil rights commission tars someone with the "brush of bigotry"? ${ }^{3}$ Is a charge of bigotry inferred simply from asserting that society should learn from the past: that now-repudiated forms of discrimination - on the basis of race and sex - are relevant to protecting against discrimination on the basis of sexual orientation? Or from comparing past religious defenses of segregation and bans on interracial marriage with religious justifications for opposing marriage by same-sex couples? Are these analogies inapt because today's sincere religious believers have nothing in common with yesterday's segregationists? Indeed, does the label "bigot" better apply to public officials who show "intolerance" toward today's sincere believers by refusing them exemptions from

\footnotetext{
* This is a draft chapter for the edited volume, ReLigious FreEdom, LGBT Rights, AND THE Prospects FOR COMMON GROUND (William S. Eskridge, Jr. \& Robin F. Wilson, eds., Cambridge University Press, forthcoming 2018). Portions of this Chapter draw from my forthcoming book, BIGOTRY, CONSCIENCE, AND MARRIAGE: PAST AND PRESENT CONTROVERSIES (under contract with Oxford University Press, forthcoming 2019), and are used with permission of the publisher.

${ }^{1}$ See, e.g., William Raspberry, Anita Bryant and Gay Rights: Bigotry or Prudence?, WASH. Post, May 2, 1977.

2135 S. Ct. 2584 (2015).

${ }^{3}$ U.S. v. Windsor, 133 S. Ct. 2675, 2696 (2013) (Roberts, C.J., dissenting) (critiquing Justice Kennedy’s majority opinion for lacking evidence to attribute "sinister motive" for the Defense of Marriage Act and "tar the political branches with the brush of bigotry"); USCCB Religious Liberty Chairman Responds to Statement of Chairman of U.S. Commission on Civil Rights, (Sept. 13, 2016), http://www.usccb.org/news/2016/16-117.cfm (quoting Archbishop Lori describing statements by Martin Castro, Chairman of the U.S. Commission on Civil Rights, as "reckless and painting those who support religious freedom with the broad brush of bigotry"). See also Lori, this volume, for view that "[t]hose who are convinced that marriage is between one man and one woman should not be equated with racial bigots).
} 
nondiscrimination laws, driving from the public square ${ }^{4}$

These controversies reveal a number of puzzles. One puzzle is whether bigotry has to do with the motivation for a belief - is sincerity a defense to bigotry? The frequent contrast between the "sincere" opponent of same-sex marriage and the "racist bigot" of the past suggests the answer is yes. Common definitions of bigotry, however, suggest the answer may be no. If the core of bigotry concerns intolerance and prejudice toward another group's beliefs or a group itself, then a sincere white supremacist or anti-Semite or anti-Muslim could still be bigoted. ${ }^{5}$

Another puzzle concerns whether bigotry refers primarily to the content of a belief, that is, an unreasonable belief or an irrational hatred or suspicion of a group, ${ }^{6}$ so that reasonableness of a belief would counter a charge of bigotry. Or does "bigot" suggest a particular type of (bad) character of the person holding the view, with distinctive psychological or moral traits — holding views about a group inflexibly and obstinately, impervious to facts? ${ }^{7}$ Or does the label "bigotry" signal an anachronistic and now-reviled view? On this definition, calling a position bigoted declares that it is (no longer) within the boundaries of civility and not an acceptable basis for supporting or opposing laws.

As a window into these puzzles, this Chapter assesses the rhetoric of "bigotry" and "conscience" in two contexts: (1) the U.S. Commission on Civil Rights Report, PEACEFUL

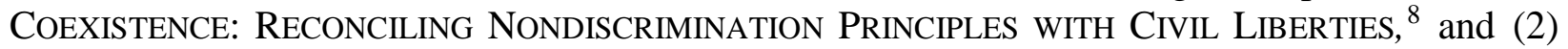
arguments made by the parties and amici curiae in Masterpiece Cakeshop. These contexts reveal a set of contrasting positions. First, defenders of religious liberty argue that to relate present-day objections based on conscience and sincerely-held religious beliefs about marriage-and related arguments that those objections warrant exemptions from nondiscrimination laws - to past assertions of religious liberty in the context of objecting to complying with civil rights laws prohibiting race discrimination brands people - indeed, slanders them - as bigots. Today's sincere Christian (or Jew or Muslim) declining to create a wedding cake or otherwise affirm same-sex marriage is nothing like the racist (past or present) refusing to serve all Black customers. And, some add, is nothing like the homophobe refusing to serve any gay or lesbian customers. Instead, people of faith have championed civil rights and justice.

\footnotetext{
${ }^{4}$ See Stephen Smith, Who's on Which Side of the Lunch Counter? Civil Rights, Religious Accommodation, and the Challenges of Diversity, PuBliC DisCOURSE, Dec. 2, 2016.

5See Bigotry, FREE DICTIONARY, http://www.thefreedictory.com/bigotry (collecting several definitions mentioning “prejudice," “intolerance," and “obtuse or narrow-minded intolerance, especially of other races or religions”).

${ }^{6}$ See id. (quoting The American Heritage Roget's Thesaurus defining “bigotry” as “irrational suspicion of a particular group, race, or religion”).

${ }^{7}$ See, e.g., Gordon W. Allport, The Bigot in Our Midst, XL THE COMMONwEAL 582, 583 (Oct. 6, 1944) (the “mental dynamics of bigotry” include the inability to take another's perspective or correct one's misinterpretations based on new information about a group); STEPHEN ERIC BRONNER, THE BIGOT: Why PREJUDICE PERSISTS 7 (2014) ("[t]he bigot's prejudices rest on pre-reflective assumptions that become fixed, finished, and irreversible in the face of new knowledge”).

${ }^{8}$ U.S. COMMISSION ON CiVIL Rights, PEACEFUl COEXISTENCE: RECONCILING NONDISCRIMINATION PRINCIPLES WITH CIVIL LIBERTIES (2016).
} 
Those defending the extension of nondiscrimination laws to protect LGBT persons counter that history teaches lessons about past assertions of conscience and religious liberty, which were used to justify many forms of discrimination and exclusion. While courts themselves, for a time, accepted - and voiced - such religious justifications, courts have, for many decades, upheld nondiscrimination laws against such challenges. This past counsels caution about arguments that "free exercise" entails living out one's faith in the public square even when that includes denying customers goods and services. Further, the framing of "religious liberty v. LGBT rights" obscures the fact that religious traditions differ in their views and also evolve, sometimes spurred by legal change. ${ }^{9}$

Second, both contexts reveal competing views of the legitimate scope of modern public accommodations laws. Invoking Chief Justice Rehnquist's opinion in Boy Scouts of America $v$. Dale, defenders of exemptions contend that the clash between religious liberty and LGBT rights stems from the (unwarranted) expansion of public accommodations laws beyond core (compelling) interests-e.g., racial discrimination in hotels, restaurants, gas stations, and entertainment venues - to cover more places and more categories, such as sexual orientation and gender identity. ${ }^{10}$ Title II of the Civil Rights Act of 1964, on this view, is the paradigm of a justified civil rights law. ${ }^{11}$

Defenders of state public accommodations laws counter that the expansion of such laws reflects evolving understanding of the problems of prejudice and discrimination. While Title II is a landmark law, many states passed public accommodations laws long before Congress did, and expanded them in light of new insights and learning. ${ }^{12}$ Apt here is Justice Stevens' statement, in his Dale dissent, that "every state law prohibiting discrimination is designed to replace prejudice with principle.”13

Third, both sides agree on the importance of civility, tolerance, and pluralism, but disagree about what those commitments require. Supporters of people "of conscience" trying to "live out their faith" in the marketplace argue that robust protection of First Amendment freedoms everywhere - including the public square - is the only path to tolerance, civility, and peaceful coexistence. Defenders of full enforcement of modern civil rights law argue that civility and tolerance require that there be limits to acting on beliefs - however sincere and religiouslymotivated - in businesses open to the public; that is the "price of citizenship" that we pay in our "civic life." "14 In a religiously diverse nation, unless certain lines are drawn, every conscience would be “"a law unto itself,"” raising "the prospect of constitutionally required religious exemptions from civil obligations of almost every conceivable kind.”15

\footnotetext{
${ }^{9}$ For calls for internal reexamination, see Gramick, this volume.

${ }^{10}$ Boy Scouts of America v. Dale, 530 U.S. 640, 664 (2000).

1142 USCA § 2000a. For discussions of Title II’s scope, see Laycock, this volume; Wilson, this volume.

12 For a chronology of state public accommodations laws extending to sexual orientation and gender identity, see Wilson, this volume.

${ }^{13}$ Dale, 530 U.S. at 664 (Stevens, J., dissenting).

${ }^{14}$ See Elane Photography, LLC v. Willock, 309 P.3d 53, 79-80 (N.M. 2013) (Bosson, J., concurring).

${ }^{15}$ Employment Division v. Smith, 494 U.S. 872 (1990) (sustaining, against a Free Exercise challenge, denial of unemployment compensation when dismissal of employees for peyote ingestion was pursuant to a neutral,
} 
This Chapter, focuses primarily on the first set of contrasting arguments, since they most directly engage the rhetoric of "bigotry" and "conscience." ${ }^{16}$ It argues that the charge leveled by proponents of robust exemptions that people are being "branded as bigots" for their beliefs is often needless and provocative when directed at explanations about the constitutional limits of using religious and moral beliefs as a basis for (1) excluding others from a constitutional right or (2) denying them the protection of civil rights law. The mere step of drawing analogies between past and present forms of discrimination to point out how evolving understandings lead to recognition that such treatment lacks justification is not - in itself - a charge of "bigotry." On the other hand, it is often needless and provocative for opponents of exemptions to indict religious belief as a "pretext" or "code word" for discrimination in order to justify limits to acting on such beliefs in the marketplace. ${ }^{17}$ This Chapter concludes with a brief comment on the oral argument in Masterpiece Cakeshop. During the argument, the parties and the justices debated the relevance of analogies to past civil rights battles and the Court's prior rulings upholding nondiscrimination laws. Also at issue was what the rhetoric of Obergefell implied about the requirements of civility and tolerance.

\section{The United States Supreme Court's Rhetoric}

The term "bigot" appears nowhere in the Supreme Court's four landmark opinions affirming the constitutional liberty and equality of gay men and lesbians: Romer v. Evans, Lawrence v. Texas, United States v. Windsor, and Obergefell. ${ }^{18}$ In Romer, however, Justice Scalia's dissent charged Justice Kennedy's majority opinion as "verbally disparaging as bigotry" the "modest attempt by seemingly tolerant Coloradans to preserve traditional sexual mores" by passing a state constitutional amendment to bar "a politically powerful minority" (homosexuals) from "revis[ing] those mores through use of the laws." ${ }^{19}$ What does it mean to "brand" someone as a bigot?

In Windsor and Obergefell, dissenters inferred a charge of bigotry from the majority's analogies between now-repudiated racial and sex-based inequality in the institution of marriage and exclusion of same-sex couples from marriage. Justice Alito pictured a future in which religious believers who "cling" to the traditional understanding of marriage could "whisper their thoughts

general applicable criminal law).

${ }^{16}$ For further elaboration, see LindA C. MCClAin, BIGOTRY, CONSCIENCE, AND MARRIAGE (forthcoming 2019).

${ }^{17}$ See infra II.A.1 for references.

${ }^{18}$ Romer v. Evans, 517 U.S. 620 (1996) (holding that Colorado’s Amendment 2, which prohibited any "protected status" based on "homosexual, lesbian, or bisexual orientation," violated the Equal Protection Clause of the Fourteenth Amendment of the U.S. Constitution); Lawrence v. Texas, 539 U.S. 558 (2003) (striking Texas law criminalizing consensual sodomy between two individuals "of the same sex" as violating constitutional "liberty" under the Due Process Clause of the of the 14th Amendment ); United States v. Windsor, 570 U.S. 744 (2013) (striking portion of federal Defense of Marriage Act defining "marriage," for purposes of all federal laws pertaining to marriage, as only between one man and one woman and operating to deny federal recognition of same-sex marriages valid under state laws as violating the Due Process Clause of the Fifth Amendment).; Obergefell v. Hodges, 135 S. Ct. 2584 (2015) (holding that same-sex couples have a fundamental right to marry as part of the "liberty" protected under the Due Process Clause of the Fourteenth Amendment).

${ }^{19}$ Romer v. Evans, 517 U.S. 620, 636, 652 (1996) (Scalia, J., dissenting). 
[only] in their recesses of their homes," fearing that "if they repeat those views in public, they will risk being labeled [and treated] as bigots." 20

The dissents also contrasted bigotry with conscience and sincerity. In Obergefell, Chief Justice Roberts contended that the Court has "disparag[ed]" as "bigoted” the millions of Americans who, "as a matter of conscience, cannot accept same-sex marriage" or the Court's "better informed understanding" of marriage. ${ }^{21}$ The passage in the Obergefell majority opinion that Roberts attacks warrants attention due to the central role it plays for both sides in post-Obergefell debates, including in Masterpiece Cakeshop. Justice Kennedy explained that constitutional rights including the "right to marry" - arise not only from "history and tradition," but also from "a better informed understanding of how constitutional imperatives define a liberty that remains urgent in our own era." ${ }^{22}$ Kennedy characterized opposition to same-sex marriage as based on "decent and honorable religious or philosophical premises," but explained: "when that sincere, personal opposition becomes enacted law and public policy, the necessary consequence is to put the imprimatur of the State itself on an exclusion that soon demeans or stigmatizes those whose own liberty is then denied." ${ }^{23}$ Kennedy later stated that the First Amendment protects the ability of opponents of same-sex marriage to teach and advocate their beliefs, but the state may not "bar same-sex couples from marriage on the same terms as accorded to couples of the opposite sex.”24

Critics of expansive nondiscrimination laws enlist Kennedy's opinion strategically to establish that believers seeking exemptions are not bigots; Obergefell promised that they would continue to be free to express their beliefs in the public square. ${ }^{25}$ Defenders of state nondiscrimination laws, in turn, enlist Obergefell's language to assert that such exemptions would put the state's “imprimatur” on religiously-motivated discrimination. ${ }^{26}$

\section{Branding as A Bigot or Learning from the Past?}

Is it instructive to relate prior assertions of religious liberty and conscience in the context of opposition to laws barring discrimination on the basis of race to present-day assertions of religious liberty in the context of laws barring discrimination on the basis of sexual orientation and gender identity? Or does drawing such analogies brand people as bigots? The PEACEFUL COEXISTENCE report ("Report") released by the United States Civil Rights Commission (“Commission”) and Masterpiece Cakeshop litigation illustrate competing answers.

\section{A. The Civil Rights Commission’s Peaceful CoeXistence Report}

The Report's “Findings and Recommendations” nowhere use the rhetoric of bigotry in

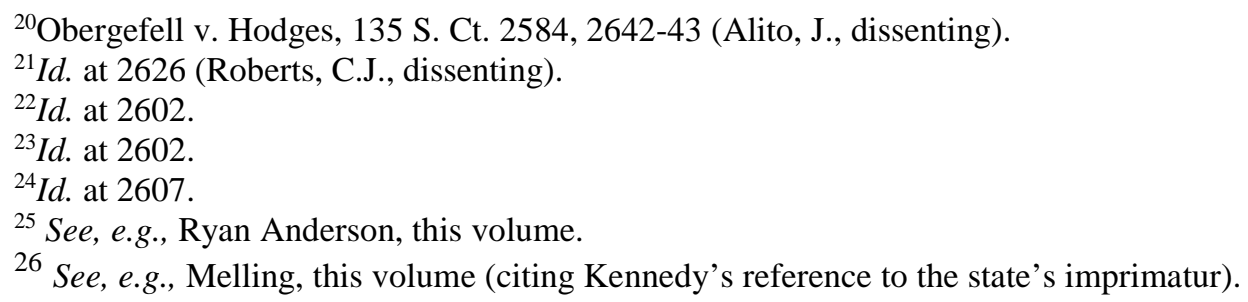


discussing the challenge of "reconciling nondiscrimination principles with civil liberties." Nonetheless, individual commissioners made oblique references to "bigotry." Parallels commissioners drew between religious justifications for racial segregation and the risks of religion - today - being used to justify "intolerance" and discrimination drew sharp criticism for "painting those who support religious freedom with the broad brush of bigotry." ${ }^{27}$ Some critics, like legal scholar Richard Epstein, asserted that the label "bigotry" better fits the "intolerant" commissioners. ${ }^{28}$

\section{Analogies to the Past}

The "Findings" link discrimination based on sexual orientation to other forms of discrimination, cautioning: "Religious exemptions to the protections of civil rights based upon classifications such as race, color, national origin, sex, disability status, sexual orientation, and gender identity, when they are permissible, significantly infringe upon these civil rights." ${ }^{29}$ The Report recommends narrow tailoring of "religious exceptions to civil liberties and civil rights" because "[o]verly-broad religious exemptions unduly burden nondiscrimination laws and policies." 30

Commission Chairman Martin R. Castro stated the following in connection with the Report's release:

The phrases "religious liberty" and "religious freedom" will stand for nothing except hypocrisy so long as they remain code words for discrimination, intolerance, racism, sexism, homophobia, Islamophobia, Christian supremacy or any form of intolerance. $^{31}$

Castro did not explicitly refer to "bigotry" in his statement. Still, "intolerance" and "discrimination" toward certain groups based on a group's belief or shared characteristic are, on many dictionary definitions, synonymous with bigotry. ${ }^{32}$

Castro insisted that the present "generation of Americans" must learn from past appeals to "religious liberty" used to justify slavery and racism:

[T]oday, as in the past, religion is being used as both a weapon and a shield by those seeking to deny others equality. In our nation's past religion has been used to justify slavery and later, Jim Crow laws. We now see "religious liberty" arguments sneaking their way back into our political and constitutional discourses ... in an effort to undermine the rights of some Americans. This generation of Americans

${ }^{27}$ USCCB Religious Liberty Chairman Responds, supra note 3.

${ }^{28}$ Richard A. Epstein, The Government's Civil Rights Bullies, DEFINING IDEAS (Sept. 26, 2016), http://www.hoover.org/research/governments-civil-rights-bullies .

${ }^{29}$ Peaceful CoeXistence, supra note 8, at 25 (Finding 3).

${ }^{30} I d$. at 26 (Recommendation 1).

${ }^{31}$ Chairman Martin R. Castro Statement, in Peaceful CoeXIStence, supra note 8, at 29.

${ }^{32}$ See Bigotry, supra note 5 (listing synonyms). 
must stand up and speak out to ensure that religion never again be twisted to deny others the full promise of America. ${ }^{33}$

A Rebuttal by several commissioners (including Castro) also shares this premise that, without vigilance, religion may be distorted to deny the equality of others. This Rebuttal also makes the implicit explicit: it does refer to bigotry and questions "sincerity." 34 The Rebuttal decries a "new wave of laws" being proposed "to limit the freedoms of [LGBT] people" and to allow public and private actors to discriminate against, including in commercial settings. The Rebuttal refers to Mississippi’s H.B. 1523 (the Protection of Conscience from Discrimination Act), North Carolina's H.B. 2, and various "bathroom bills” requiring transgender persons to use public facilities corresponding to their sex at birth. ${ }^{35}$ This Rebuttal asserts (in a section title): "These laws and proposals represent an orchestrated, nationwide effort by extremists to promote bigotry, cloaked in the mantle of "religious freedom." 36

Critics of the Report viewed the findings and recommendations and the commissioners' statements quoted above as tarring believers with the "brush" of bigotry. Commissioner Peter Kirsanow states that the "findings and recommendations lend credence to" Justice Alito's warnings, detailed above. ${ }^{37}$ Kirsanow insisted that religious individuals "just want to be left alone" and not be forced by government - through nondiscrimination laws - to "associate" or to "speak." 38

In her statement and rebuttal, Commissioner Gail Heriot quotes the prediction by legal scholar Mary Ann Glendon, in 2004 after Massachusetts began allowing same-sex couples to marry, of a "new era of intolerance and discrimination," in which "[e]very person and every religion that disagrees will be labeled as bigoted and openly discriminated against." 39

Critical reactions to the Report focus particularly on Chairman Castro's statement. ${ }^{40}$ In a letter to President Obama, Senator Hatch, Representative Ryan, Archbishop Lori, and sixteen other “American faith leaders” expressed “deep concern” about the Report. Citing Castro's statement, the letter demands that "no American citizen or institution be labeled by their government as bigoted because of their views and dismissed from the political life of our nation for holding those views." 41

\footnotetext{
${ }^{33}$ Castro Statement, supra note 31, at 29.

${ }^{34}$ Commissioners Achtenberg, Castro, Kladney, Narasaki, and Yaki Rebuttal, in PeACEFUl CoeXISTENCE, supra note 8 , at $155,160$.

${ }^{35}$ For critique of these laws, see Melling, this volume; Pizer, this volume; Wilson, this volume.

${ }^{36} I d$. at 160 (emphasis added).

${ }^{37}$ Commissioner Peter Kirsanow Statement, in Peaceful CoeXistence, supra note 8, at 42, 105.

${ }^{38}$ Id. at 123.

${ }^{39}$ Mary Ann Glendon, For Better for Worse, WALL ST. J. (Feb. 25, 2004) (quoted in Commissioner Gail Heriot Statement and Rebuttal, in PEACEFUl CoEXISTENCE, supra note 8, at $151 \mathrm{n}$. 52).

${ }^{40}$ Nicholas Senz, Obama Administration Says You're a Bigot if You Live Your Religion, FedERALIST (Sep. 19, 2016), http://thefederalist.com/2016/09/obama-administration-says-youre-bigot-live-religion.

${ }^{41}$ Letter from Most Reverend William E. Lori and others to President Obama, Hon. Orrin G. Hatch, and Congressman Paul Ryan, October 7, 2016.
} 


\section{Flipping the Charges of Bigotry and Intolerance}

Some critics of the Report not only reject its implicit or explicit charge that opponents of nondiscrimination laws protecting LGBT people are bigots; they flip the charges of bigotry. Epstein insists that business owners who seek to live - and do business - according to their religious beliefs and are willing generally to serve gay and lesbian customers are not bigots. When they decline to violate their beliefs by helping to celebrate a same-sex marriage, they "bear[] no relationship to a 'prejudiced or close-minded person, especially one who is intolerant or hostile towards different social groups." 42 By comparison:

[T]he words "bigotry" and "phobia" clearly do apply to the five commissioners who happily denounce people like Stutzman [a florist who declined to arrange flowers for a gay customer's wedding] . . . . They show no tolerance, let alone respect, for people with whom they disagree. . . . They show deep prejudice and hostility to all people of faith. ${ }^{43}$

Simply to point out the appeal to religion in justifying prior forms of discrimination, as Castro does, is not to argue that religious beliefs equal bigotry. That said, there are better ways to express this point than Castro's rhetoric of pretext and weaponizing religion, as some of the arguments made in Masterpiece Cakeshop illustrate.

\section{B. Masterpiece Cakeshop}

In Masterpiece Cakeshop, the Supreme Court will decide the appeal of the self-described “cake artist” Jack Phillips, who asks the Court to decide "whether applying Colorado's public accommodations law to compel artists to create expression that violates their sincerely held religious beliefs about marriage violates the Free Speech or Free Exercise Clauses of the First Amendment." 44 Phillips, the owner of Masterpiece Cakeshop, appeals a decision by the Colorado Court of Appeals that he violated the public accommodations provision of the Colorado Antidiscrimination Act ("CADA") when, citing his religious beliefs, he declined to bake a cake for a celebration of Charlie Craig and David Mullins' wedding ceremony. The Colorado Court of Appeals affirmed a prior decision by the Colorado Civil Rights Commission, which upheld an administrative law judge's decision that Phillips violated CADA and that denying him an exemption did not violate his First Amendment rights. ${ }^{45}$

The rhetoric of bigotry and conscience has been deployed in this litigation by both sides to analogize between past and present civil rights battles. This Section first examines arguments made by Phillips and his amici, then considers arguments made by respondents Colorado Civil Rights

\footnotetext{
42 Epstein, supra note 28 (using Wikipedia’s definitions).

${ }^{43} I d$.

${ }^{44}$ Brief for Petitioners, Masterpiece Cakeshop et al. v. Colorado Civil Rights Commission et al., No. 16111 , at I.

${ }^{45}$ Craig v. Masterpiece Cakeshop, 370 P.3d 272 (Col. Ct. App. 2015), cert denied sub nom Masterpiece Cakeshop v. Colorado Civil Rights Commission, 2016 WL 1645027 (Colo. 2016).
} 
Commission ("CCRC”), Craig and Mullins, and their amici. On each side, only a minority of the amicus briefs explicitly use the rhetoric of bigotry-14 of those filed in support of Phillips; 9 of those filed in support of respondents. ${ }^{46}$ It is instructive to examine the usage of that term.

\section{Arguments by Phillips and His Amici}

Phillips and his amici contend that compelling him to "design" a "custom" wedding cake for a same-sex couple unconstitutionally forces him to "celebrate same-sex marriage," which he "in good conscience" cannot do, since he "seeks to live his life, pursue his profession, and craft his art consistently with his religious identity." 47 Phillips argues Colorado violated the First Amendment by compelling a private citizen "'to utter what is not in his mind." 48 In support, Phillips invokes the famous compulsory flag salute case, West Virginia v. Barnette. ${ }^{49}$

These briefs also quote from Justice Kennedy’s majority opinion in Obergefell and argue that a ruling against Phillips would fail to realize Obergefell's "laudable effort to promote tolerance and mutual respect in a pluralistic national community." ${ }^{50}$ Unless the Supreme Court reverses, the amici contend, it will send a message that Phillips is a bigot, a pariah, properly excluded from the public square - contrary to Obergefell's "promise" to conscientious dissenters about their First Amendment rights. The path to peaceful coexistence lies in exemptions in case of such "decent and honorable" beliefs, so that people of faith are not driven from public life. ${ }^{51}$ Their dignitary and other interests are harmed far more than those of a would-be customer denied service in the current gay-friendly marketplace. ${ }^{52}$

\section{a. Showing “Hostility” Toward Phillips’s Religion}

Phillips and several of his amici assert that the CCRC and the Colorado appellate court showed "hostility" toward his religion. They cite this remark made by a commissioner in proceedings before the CCRC:

Freedom of religion and religion have been used to justify all kinds of discrimination throughout history, whether it be slavery, whether it be the $[\mathrm{H}]$ olocaust, . . . we can list hundreds of situations where freedom of religion has been used to justify discrimination. And to me it is one of the most despicable pieces of rhetoric that people . . use their religion to hurt others. ${ }^{53}$

\footnotetext{
${ }^{46}$ This count reflects electronic searches of the briefs for "bigot,” "bigoted,” and "bigotry."

${ }^{47}$ Brief for Petitioners, supra note 44, at 14-17.

${ }^{48} I d$. at 2 .

${ }^{49}$ Id. at 3, 15 (citing W. Va. Bd. v. Barnette, 319 U.S. 624 (1943)). This chapter focuses more on Phillips's Free Exercise claim than his compelled expression/speech claim.

${ }^{50}$ Brief of Amici Curiae 34 Legal Scholars in Support of Petitioners, Masterpiece Cakeshop et al. v. Colorado Civil Rights Commission et al., No. 16-111, at 14-17, at 27. All the amicus briefs from this litigation are available at: http://www.scotusblog.com/case-files/cases/masterpiece-cakeshop-ltd-v-colorado-civil-rights-commn/.

${ }^{51}$ For similar views in this volume, see Ryan Anderson.

${ }^{52}$ For other weighing of burdens, see Laycock, this volume.

${ }^{53}$ Brief for Petitioners, supra note 44, at 43.
} 
Amici Liberty Counsel argues this remark illustrates that CCRC has "fully embraced [the idea] that religious beliefs must take a back seat to eliminating what it views as discrimination based on sexual orientation, because religious freedom is just an excuse to justify hurting other people."54 Phillips argues that the CCRC's “disdain” for his "religious views” is also evident from its permitting three other bakers to decline to create cakes with "offensive” messages expressing disapproval of same-sex marriage. ${ }^{55}$ Amici William Jack, who requested those three cakes, contends that the CCRC "expressed hostility towards [his] traditional religious views" as being "odious." 56

It bears noting that, in affirming the CCRC's ruling against Phillips, the Colorado Court of Appeals neither denied the "sincerity" of Phillips's religious beliefs about marriage nor called him a "bigot." The court did, however, draw on precedents rejecting religious defenses to public accommodations laws to explain that the freedom to act on religious beliefs has limits. It cited Newman v. Piggie Park Enterprises, a 1966 case in which the federal district court in South Carolina refused "to lend credence or support to [the restaurant owner's] position that he has a constitutional right to refuse to serve members of the Negro race in his business establishment upon the ground that to do so would violate his sacred religious beliefs.” 57 Quoting Piggie Park, the Colorado court explained that, while free exercise includes a "right to espouse beliefs of [one's] own choosing,"” it does not include " "the absolute right to exercise and practice such beliefs in utter disregard of the clear constitutional rights of other citizens." "58 So, too, the court reasoned, if Masterpiece Cakeshop wishes to operate as a "public accommodation" and "conduct business" in Colorado, CADA "prohibits it from picking and choosing customers based on their sexual orientation." 59

In concluding that CADA, a neutral law of general applicability, was constitutional, the court related the United States Supreme Court's recognition of states' “compelling” interest in eliminating discrimination on the basis of race and sex in places of public accommodation to Colorado's interest in eliminating discrimination in such places on the basis of sexual orientation. It concluded that CADA "creates a hospitable environment for all consumers," which "prevents the economic and social balkanization prevalent when businesses decide to serve only their own 'kind.'”60

\section{b. Merchants of "Good Conscience” are not Bigots}

Phillips and his amici contrast the religious believer with "decent and honorable” beliefs

\footnotetext{
${ }^{54}$ Brief of Amicus Curiae Liberty Counsel in Support of Petitioner Seeking Reversal, at 40.

${ }^{55}$ Brief for Petitioners, supra note 44 , at $40-43$.

${ }^{56}$ Brief of Amici Curiae William Jack and the National Center for Law and Policy in Support of Petitioners, at 2, 16.

${ }^{57}$ Craig, 370 P.3d at 280.

${ }^{58}$ Id. at 291 (quoting Newman v. Piggie Park Enterprises, 256 F. Supp. at 941, 945 (D.S. C. 1966), aff'd, 377 F.2d 433 (4 $4^{\text {th }}$ Cir. 1967), aff'd, 390 U.S. 400 (1968) (per curiam)).

${ }^{59}$ Id. at 292.

${ }^{60} \mathrm{Id}$. at $293-94$.
} 
about marriage with the racist and the homophobe. Phillips, "a conscientious man of faith," "gladly serves people from all walks of life, including individuals of all races, faiths, and sexual orientations," but simply "declines all requests . . . to create custom artistic expression that conflicts with his faith." 61 This conscience-driven refusal to express a message, in this instance "celebrating same-sex marriage," one amicus argues, is not the "invidious discrimination" like that at the core of laws banning discrimination in public accommodations; in those instances, "a merchant objects to serving some people just because and on the ground that they are black, or female ... or gay.” 62

A number of amici enlist the rhetoric of bigotry in urging the Supreme Court to reverse. In arguing that Phillips has been "branded" a bigot, some remind the Court of the prediction in Justice Alito's Obergefell dissent: "Colorado has unquestionably labeled and treated Petitioner as a bigot." 63 The amicus curiae brief filed by Sherif Girgis and Robert George suggests that denying Phillips's claim will "tell him - and all traditional Muslims, Orthodox Jews, and Christians - that acting on beliefs central to his identity is wrong, benighted, even bigoted;" Obergefell "expressly" rejects sending such a message. ${ }^{64}$ Asserting that Craig and Mullins "suffered no material harm" from Phillips' refusal, another amicus curiae brief emphasizes the harms suffered by Phillips: "the State has effectively branded him a bigot and rendered him something of an outcast, seriously harming his reputation in the community."65

\section{c. Rejecting Analogies to Past Civil Rights Struggles}

Amici for Phillips argue that past civil rights struggles are not relevant to Phillips' refusal of service to Craig and Mullins: "Public-accommodations concerns of past eras are not present here." ${ }^{66}$ One reason is that "the artist plainly did not act out of invidious discrimination" but instead out of concern not to "violate [his] conscience." ${ }^{67}$ Another is the distinction between genuine public accommodations, "like restaurants and hotels," and "customized pieces of art," like wedding cakes. ${ }^{68} \mathrm{~A}$ third is that Craig and Mullins "had immediate access to other artists," ${ }^{69}$ unlike discriminated-against minorities under the Jim Crow practices that Title II sought to end. Some amici treat Title II as the paradigm of a narrowly-tailored public accommodations law, contrasting CADA as an inappropriate expansion of nondiscrimination law that, instead of remedying discrimination, now is a "source" of it. ${ }^{70}$ Such expansion has led, as Chief Justice Rehnquist predicted in Dale above, to clashes with First Amendment rights.

\footnotetext{
${ }^{61}$ Brief for Petitioners, supra note 44, at 8-9, 52.

${ }^{62}$ Brief of Amici Curiae 34 Legal Scholars, supra note 50, at 13.

${ }^{63}$ Brief of North Carolina Family Values Coalition and the Family Research Council as Amici Curiae in Support of Petitioners, at 22.

${ }^{64}$ Brief of Amicus Curiae Sherif Girgis Supporting Petitioners, at 17. Robert George appears as counsel of record.

${ }^{65}$ Brief of the Ethics \& Religious Liberty Commission of the Southern Baptist Convention et al. in Support of Petitioners, at 30.

${ }^{66}$ Brief for the States of Texas, Alabama, et al. as Amici Curiae in Support of Petitioners, at 3.

${ }^{67} \mathrm{Id}$. at 3.

${ }^{68} \mathrm{Id}$. at 3.

${ }^{69} \mathrm{Id}$.

${ }^{70}$ Brief of Liberty Counsel, supra note 54, at 18.
} 
Other amici concede the general legitimacy of including "sexual orientation" protections in nondiscrimination law, but argue that goods and services related to same-sex weddings are a special case. One brief asserts that Phillips simply refuses to "use his artistic gifts to provide a particular service" because he believes it "contrary to God's law and biblical teachings."71 Notably, the amicus brief filed by Utah Republican State Senators argues that, "in Republicancontrolled 'red' states, the lack of protections for LGBT [sic] in places of public accommodations leave them exposed to potential abuses most Americans would find deplorable." ${ }^{72}$ But red states like Utah, they argue, have not extended their public accommodations law to include "sexual orientation" out of concern that such laws might not adequately protect the First Amendment rights of "conscientious objectors" like Phillips. ${ }^{73}$

\section{d. Downplaying the Role of Religion in Past Defenses of Racism and Discrimination}

Some amici reject any comparison between Phillips’s “decent and honorable” beliefs about marriage and religious justifications for segregation and anti-miscegenation laws. For example, in his brief, Ryan T. Anderson of the Heritage Foundation (who is also writing for this volume) contrasts opposition to interracial marriage, rooted in "racist bigotry," with support for marriage as a "conjugal union of husband and wife," rooted in "decent and honorable premises." 74

To rule for Phillips would send "no message about the supposed inferiority of people who identify as gay," but instead a message "that citizens who support the historic understanding of marriage are not bigots and that the state may not drive them out of business and civic life." 75

Anderson downplays the pervasiveness and sincerity of religious rationales marshaled in the past for racial segregation and against interracial marriage: the "wicked system of white supremacy” was rooted in "bigotry," "animus," and convictions about racial hierarchy. For Anderson, political leaders' appeal to theology to justify racial "subordination" showed how religion "was perverted to justify racism and slavery." segregationists vehemently denied charges of bigotry and insisted they were waging a war of morality and conscience, with God on their side. ${ }^{77}$ The "the theology of segregation" sounded in

${ }^{71}$ Brief of Amici Curiae 34 Legal Scholars, supra note 50, at 26.

${ }^{72}$ Brief of Amici Curiae Utah Republican State Senators in Support of Petitioners and Reversal, at 3. The brief notes that Utah passed "compromise" legislation "add[ing] sexual orientation to the state's housing and employment discrimination laws," in employment and housing, but could not reach agreement on a similar expansion of its public accommodations law. Id. at 24-25. For an account of Utah's law and why it did not address public accommodations, see Adams, this volume.

${ }^{73}$ Brief of Amici Curiae Utah Republican State Senators, supra note *, at 4-11.

${ }^{74}$ Amicus Curiae Brief of Ryan T. Anderson, Ph.D. and African-American and Civil Rights Leaders in Support of Petitioners, at 3-4. See also Ryan Anderson, this volume (urging that governments can "address minorities' precise needs without punishing reasonable citizens for acting on decent and honorable beliefs).

${ }^{75}$ Amicus Curiae Brief of Ryan T. Anderson, supra note 74, at 3-4. See also Ryan Anderson, this volume, for similar claim that protecting Phillips' "freedom here sends no message about the supposed inferiority of those identifying as gay; it sends no message about sexual orientation at all. It says that citizens who support the historic understanding of sex and marriage are not bigots").

${ }^{76}$ Amicus Curiae Brief of Ryan T. Anderson, supra note 74, at 15-16.

${ }^{77}$ For examples, see McClain, supra note 16. 
pulpits and pages of the Congressional Record. ${ }^{78}$ Further, even some who came to oppose legal segregation believed that there were "decent and honorable" grounds for opposing interracial marriage. In 1963, when asked whether racial integration would lead to “inter-marriage,” President Harry Truman, who issued an executive order initiating the desegregation of the military and created the President's Commission on Civil Rights, answered: "I hope not. I don't believe in it. The Lord created it that way. You read your Bible and you'll find out."79

\section{e. The Demands of Tolerance}

Some amici assert that Colorado has been intolerant toward Phillips and his sincere religious beliefs. Thus, Epstein repeats the charges of intolerance he sounded against Commissioners on the U.S. Civil Rights Commission, decrying "state coercion" against "the few vulnerable family firms" - like Masterpiece - that raise conscience-based objections;" the brief asserts that Phillips "and others like him have repeatedly been victimized by such actions." 80 Another brief asserts that "secular ideologies increasingly employ the strong arm of the state to advance their causes, promoting tolerance and respect for some while ruthlessly suppressing others," forgetting that "tolerance is a two-way street." 81 This argument that Colorado was intolerant toward Phillips prefigures Justice Kennedy's chiding of Colorado at oral argument that "tolerance is most meaningful when it's mutual;" Colorado, Kennedy asserted, "has been neither tolerant nor respectful of Mr. Phillips’ religious beliefs.”82

\section{Arguments by Respondents and their Amici}

Of the forty-six amicus briefs filed on behalf of respondents CCRC and Craig and Mullins, only nine explicitly use the terms "bigot," bigoted," or "bigotry," and just six do so in their argument. ${ }^{83}$ None explicitly labels Phillips a bigot. Do they, nonetheless, imply that he is one? This Section examines some of those briefs, using one as a doorway into examining an argument that some commentators view as labeling religious persons as bigots: "we have heard this before and should learn the lessons of history." Many amici argue that the long history of asserting a variety of First Amendment justifications for racial and sex discrimination - and of courts eventually rejecting such justifications - affords reasons for courts to reject present-day religious and other justifications for sexual orientation discrimination in the context of marriage, or, more broadly, for LGBT discrimination. The same “principles” that underlie landmark federal public accommodations laws apply to the expansion of state laws to include sexual orientation (and, some amici add, gender identity). They warn that recognizing exemptions based on conscience or religious beliefs threatens to reverse hard-won progress in protecting civil rights and may put the

\footnotetext{
${ }^{78}$ See, e.g., Reverend G.T. Gillespie, A Southern Christian Looks at the Race Problem, SOUTHERN Presbyterian Journal (June 5, 1857), reprinted at 103 Cong. Rec. A6511 (Aug. 9, 1957) (85 ${ }^{\text {th }}$ Cong., $1^{\text {st }}$ Sess.).

${ }^{79}$ JAMES E. FLEMING AND LINDA C. MCClAin, ORDERED LIBERTY 173 (2013) (citation omitted).

${ }^{80}$ Brief of Amici Curiae Law and Economics Scholars in Support of Petitioners, at 22-23.

${ }^{81}$ Brief of North Carolina Values Association, supra note 63, at 3-4.

82 Transcript of Oral Argument, Masterpiece Cakeshop v. Colorado Civil Rights Commission, No. 16-111, at 62 .

${ }^{83}$ Three amicus briefs refer to "bigotry" only in the statements of interests of amici as organizations dedicated to fighting bigotry.
} 
state’s “imprimatur” on discrimination.

\section{a. Do Amici Brand Phillips as a Bigot?}

The amicus brief filed by the Lambda Legal Defense and Education Fund et al. refers to bigotry not in marketplace discrimination but in violence against LGBT persons:

Because anti-LGBT discrimination is pervasive and results in fears that hostility may lurk behind any counter or storefront, this community has created "safe spaces," in which to relax and let down their guard. . .. Tragically, as the violent Pulse nightclub massacre in Florida last year shows, even in such safe spaces members of the LGBT community may be targets of lifeshattering, even life-ending bigotry. ${ }^{84}$

Putting the stamp of governmental approval on discrimination has "dangerous repercussions," including more discrimination and an increased risk of anti-LGBT violence. The brief mirrors the PeAceful Coexistence Report in defending Colorado's nondiscrimination law's choice of “a path of peaceful coexistence and equal access in public life." 85 The brief does not question the sincerity of Phillips' religious belief, but explains the "dangerous ripple effects" of recognizing religious or creative expression exemptions to nondiscrimination laws. Enlisting Obergefell, the brief cautions: “When even 'sincere, personal opposition' to treating LGBT people equally 'becomes enacted law and public policy, the necessary consequence is to put the imprimatur of the State itself on exclusion that soon demeans or stigmatizes those whose own liberty is then denied." 86

A second brief does not explicitly call Phillips a bigot, but observes that Loving and Bob Jones University illustrate that "much prejudice against people of different races in the United States was justified on religious grounds, and racists often still base their bigotry on their religious faith." 87 The brief warns that precedents like Bob Jones might be at risk if the Court allows "religious preferences and beliefs" to be sufficient to exempt Phillips from CADA. The brief counters Phillips's theory that Craig and Mullins suffered minimal harm, being denied service at a particular business: "The true harm comes from being the victim of bigotry, and not necessarily that from the inconvenience of seeking alternative providers.” 88

A third brief states: "CADA forbids discrimination on the basis of sexual orientation whether motivated by pure bigotry, secular morality, or religious belief." ${ }^{9}$ The brief presents Phillips's free exercise claim as a "sympathetic case," posing a dilemma of "conscience." Nonetheless, invoking Smith, it warns that there is no principled limit to the conscience exemption Phillips seeks, anticipating numerous clashes between "commands of conscience" and laws "that

\footnotetext{
${ }^{84}$ Brief of Amici Curiae Lambda Legal Defense and Education Fund, Inc. et al. in Support of Respondents, at $37-38$.

${ }^{85} \mathrm{Id}$. at 3.

${ }^{86}$ Id. at 39-40 (quoting Obergefell, 135 S. Ct. at 2602).

${ }^{87}$ Brief of Amici Curiae the Center for Inquiry et al. in Support of Respondents, at 25.

${ }^{88}$ Id. at 26, 27.

${ }^{89}$ Brief of Church-State Scholars as Amici Curiae in Support of Respondents, at 4.
} 
protect fundamental rights, equal protection, health and safety, free markets, or other social goods." 90

A fourth brief that mentions "bigotry," filed by the Central Conference of Rabbis, rejects the oppositional framing of "religious liberty versus LGBT rights," pointing to "broad religious support for LGBT nondiscrimination." 91 The explicit reference to bigotry occurs when the brief recounts some religious leaders' opposition to Mississippi’s HB 1523: "Rabbi Jeffrey Simons perceived [HB 1523] as being 'not about religion . . . [but] about bigotry.", 92

Another brief critiques the claim by Phillips and his supporters that people of faith are being branded as bigots when public accommodations laws are applied to them: "Opponents contend that they are the victims of secularism - positioned as bigots and pariahs - then leverage that narrative to assert that they are not bigots at all because they are not discriminating based on sexual orientation. Instead, they are making a choice to reject conduct - marriage." 93 The brief positions this attempt to distinguish between identity (status) and conduct (marriage) in a longer history of opposing "civil rights gains for the LGBT community.” Notably, this brief does not rely on analogies to racial discrimination, but charts the shifting rationales offered to oppose civil rights for LGBT people, interlacing the Court's own trajectory from Bowers v. Hardwick to Obergefell and its rejection of the status-conduct distinction. ${ }^{94}$

\section{b. Learning From the Past}

The amicus brief filed by Massachusetts, along with eighteen other states and the District of Columbia, illustrates a theme in many briefs filed in support of upholding Colorado's law: : "history has taught us to be wary" of the assertion of Free Exercise claims to justify "refus[ing] equal service to certain members of the public based on its owner's personal beliefs." 95 Public accommodations laws are "a centerpiece of state efforts to combat the economic, personal, and social harms caused by invidious discrimination,” including that experienced by LGBTQ people. ${ }^{96}$

The argument that "we have heard this kind of claim before" 97 draws directs analogies between the role of religious beliefs to justify racial and sexual orientation discrimination. In Piggie Park, the brief observes, the Supreme Court characterized as "patently frivolous" the business owner's assertion of a constitutional right not to violate his "sacred religious beliefs" about segregation as the reason for his "refusal to serve members of the Negro race." 98 It then

${ }^{90}$ Id. at 12 (quoting Smith, 494 U.S. at 890). For other discussion of Smith, see Brownstein, this volume;

Laycock, this volume; Krotoszynski, this volume.

${ }^{91}$ Brief for Amici Curiae the Central Conference of Rabbis in Support of Respondents, at 18-19.

${ }^{92}$ Id. at 20 (citation omitted).

${ }^{93}$ Brief of Amici Curiae Legal Scholars in Support of Equality in Support of Respondents, at 10.

${ }^{94}$ Id. at 14-19.

${ }^{95}$ Brief of Massachusetts et al. as Amici Curiae in Support of Respondents, at 2.

${ }^{96} I d$. at 2, 4-10. For an argument that LGBT discrimination is separable from the invidious discrimination that provoked Title II, see Ryan Anderson, this volume.

${ }^{97}$ Brief of Massachusetts et al., supra note 95, at 2.

${ }^{98}$ Id. at 26 (citing Piggie Park, 390 U.S. at 402 n.5). 
asserts: "Businesses today have no more of a right to justify their discrimination against LGBTQ individuals on religious grounds."

Motive for discrimination, the brief insists, does not matter. Thus, to Phillips' question "whether the States' compelling interest in combatting discrimination extends to discrimination motivated by 'sincerely held religious beliefs," the brief insists "the answer is a resounding 'yes."”99

The Massachusetts brief's single reference to "bigotry” appears in the context of citing the recent violence in Charlottesville and the sizable minority of the public who disapprove of interracial marriage:

It remains a sad fact of American society that bigoted beliefs are disturbingly prevalent. Under Petitioners' theory, an anti-Semitic baker could refuse to sell a wedding cake to a Jewish couple because he does not wish 'to create expression that he considers objectionable.' . . And a racist architect could refuse to design a family home for an interracial couple on the same grounds. 100

While the First Amendment "tolerates all manner of odious speech in the public square," the brief adds, it does not insulate businesses from liability for such refusals. ${ }^{101}$

The NAACP Legal Defense and Education Fund also sounds the theme of learning from history, relating the denial of service to three would-be customers in 2012 - Mr. Mullins, Mr. Craig, and Mr. Craig's mother - to the denial of service at a barbeque to three African-American customers in 1964 - leading to Piggie Park. ${ }^{102}$ The brief observes that, at the time of the Court's decision, the restaurant owner's "religious beliefs were relatively mainstream." He was not viewed as "fringe or disingenuous," making the Court's ruling all the more significant. ${ }^{103}$

This brief highlights the appeal to religious beliefs to justify now-repudiated forms of discrimination, emphasizing that such beliefs were not isolated, marginal positions, but sincerely and widely held and articulated. "[T] he overarching lesson of Piggie Park, Bob Jones, and Loving is that this Court has repeatedly and unambiguously rejected religious-based justifications for differential treatment ... for good reasons: the government has a compelling interest in combating discrimination in its various forms." ${ }^{104}$ Amicus American Bar Association adds that such "historic decisions" as Piggie Park and Bob Jones contributed to the eventual emergence of a "settled social consensus" despite the many "passionate" and "sincere" moral and religious objections to Title II: "business owners who offer their goods and service to the public cannot claim constitutional

\footnotetext{
${ }^{99}$ Brief of Massachusetts et al., supra note 96, at 21.

${ }^{100} \mathrm{Id}$. at 32.

${ }^{101} \mathrm{Id}$.

$2-3$.

${ }^{102}$ Brief of Amicus Curiae NAACP Legal Defense \& Educational Fund, Inc. in Support of Respondents, at

${ }^{103} \mathrm{Id}$. at 14 (citing media coverage of Mr. Bessinger).

${ }^{104}$ Id. at 15.
} 
sanctuary from public accommodations laws.”105

At the Masterpiece Cakeshop oral argument, the liberal justices brought up Piggie Park, along with other civil rights era cases, in questioning petitioners' First Amendment claims. ${ }^{106}$ They expressed concern that an exemption could undermine the entire structure of nondiscrimination laws. ${ }^{107}$ On the other hand, after observing that "the racial analogy obviously is very compelling," Chief Justice Roberts pointed out that Obergefell "went out of its way to talk about the decent and honorable people who may have opposing views." ${ }^{108}$ Phillips, on this reading of Obergefell, is morally distinct from a racist. Whether this distinction is enough to justify exempting him from Colorado's laws remains to be seen.

\section{Conclusion}

Charges of "branding as a bigot" often stem from analogies between past and present forms of exclusion and injustice. These charges are often needless and provocative. The mere step of drawing analogies between past and present forms of discrimination to point out how, over time, new insights and evolving understandings lead to recognition that such treatment lacks justification is not a charge of "bigotry." Nor should a charge of bigotry be inferred simply from explanations about the constitutional limits of using religious and moral beliefs as a basis for (1) excluding others from a constitutional right (such as the fundamental right to marry) or (2) denying them the protection of civil rights laws. On the other hand, it is needlessly provocative to indict religious beliefs as a "pretext" or "code word" for discrimination in order to explain that there must be limits to acting on such beliefs - however sincere - in the marketplace. The better path, modeled by Justice Bosson's concurring opinion in Elane Photography, is to speak in terms of the requirements of civility and tolerance, or the "price of citizenship" in a pluralistic society. ${ }^{109}$ Bosson attempted to address the business owners "with utmost respect," while explaining that their freedom to live out their religious beliefs "wherever they lead" in their personal lives must have some limits in "our civic life," including public accommodations. He focuses on the strength of the state's interest in the terms of that civic life to show the force of analogy: "the [state] legislature has made it clear that to discriminate in business on the basis of sexual orientation is just as intolerable as discrimination directed toward race, color, national origin, or religion.” 110

What will the Supreme Court say about whether this "price of citizenship" is too high? It is always difficult to read tea leaves predicting the outcome in closely-watched cases, but the oral argument suggested that concern for "tolerance and mutual respect" may prove key to Justice Kennedy, widely believed to be the crucial fifth vote for the majority. Kennedy appeared troubled both by Phillips's efforts to draw lines to carve out an exception from state nondiscrimination laws for "compelled expression" and by a lack of tolerance and respect shown by the Commission

${ }^{105}$ Brief of the American Bar Association as Amici Curiae In Support of Respondents, at 5, 21.

${ }^{106}$ Oral Argument, supra note 82, at 20-21 (Justice Sotomayor).

${ }^{107}$ Id. at 43-44 (Justice Souter).

${ }^{108}$ Id. at 73.

${ }^{109}$ See Elane Photography, 309 P.3d at 79-80 (Bosson, J., concurring).

${ }^{110} \mathrm{Id}$. 
toward Phillips's religion. Kennedy focused on whether the comment of one of the commissioners, discussed above, expressed "hostility" toward Phillips' religion. Kennedy chided counsel for the CCRC for its treatment of Phillips, admonishing that "tolerance is essential in a free society" and should be "mutual." 111 Kennedy also seemed sympathetic to the argument that public accommodations laws like CADA could exempt merchants like Phillips, so long as a gay couple could readily find the same good or service elsewhere. Even so, he expressed concern that a ruling for Phillips could allow a "boycott" of "gay marriage" and be "an affront to the gay community." 112 Perhaps the Court may avoid ruling on the merits, given the many quagmires about finding any line that would not undermine nondiscrimination law - not to mention its own precedents (including Obergefell). It might, for example, remand to afford the Commission (minus the "hostile" Commissioner) or the Colorado legislature a chance to craft some kind of exemption that would not be an "affront" to would-be customers like Craig and Mullins, but also show (in Kennedy's words) more tolerance and respect toward Phillips. If nothing else, the Masterpiece litigation shows the many constitutional and political commitments at stake and the importance from learning from the past as states attempt to protect against discrimination, based on evolving insights and understandings. The path forward from Obergefell to a more tolerant and respectful society is being charted by the Court, federal and state lawmakers, civil rights advocates, and scholars in volumes like this.

${ }^{111}$ Oral Argument, supra note 82, at 62.

${ }^{112}$ Id. at 27. 